\title{
Detection of Emerging Food Pathogens in Chicken Meat Using Multiplex Polymerase Chain Reaction
}

\author{
Satheesh Raja ${ }^{1}$, Appa Rao ${ }^{1}$, Narendra Babu ${ }^{1} \&$ Thamizhannal $^{1}$ \\ ${ }^{1}$ Department of Meat Science and Technology, Madras Veterinary College, TANUVAS, Tamil Nadu, India \\ Correspondence: Satheesh Raja, Department of Meat Science and Technology, Madras Veterinary College, \\ TANUVAS, Tamil Nadu, India. Tel: 96-7768-8989. E-mail: drsatheeshtyke@gmail.com
}

Received: June 11, 2016

doi:10.5539/jas.v8n9p217
Online Published: August 15, 2016

URL: http://dx.doi.org/10.5539/jas.v8n9p217

\begin{abstract}
A study was undertaken to develop a multiplex PCR (m-PCR) protocol for simultaneous detection of Campylobacter jejuni and Listeria monocytogenes in chicken meat. The extraction of DNA was carried out using commercial DNA extraction kit, Phenol Chloroform and boiling method. Samples with OD ratio (260:280) between 1.7 and 1.9 were considered good in terms of concentration and purity and were used for PCR amplification. DNA extraction kit and Phenol Chloroform method revealed good OD value were used for sample extraction process. PCR and m-PCR amplification was carried out using genus specific primers were designed by targeting its Hyp (500 bp) and prfA (290 bp) gene for Campylobacter jejuni and Listeria monocytogenes respectively. Electrophoresis of amplified PCR products and gel documentation revealed $500 \mathrm{bp}$ and $290 \mathrm{bp}$ in 2\% Agarose. The multiplex PCR technique was standardized using the reference strains with the similar amplification procedure. The minimum detection level (sensitivity) by MPCR for Campylobacter jejuni and Listeria monocytogenes was found to be $0.2 \mathrm{ng} / \mu \mathrm{l}$ and $1.0 \mathrm{ng} / \mu \mathrm{l}$ of DNA in a reaction mixture $(25 \mu \mathrm{l})$. The developed multiplex PCR technique could detect Campylobacter jejuni and Listeria monocytogenes upto $3 \times 10^{5}$ and $3 \times 10^{4} \mathrm{CFU} / \mathrm{ml}$ of artificially inoculated meat homogenate. Around 60 chicken meat samples were collected from different regions of chennai and were screened for the presence of Campylobacter jejuni and Listeria monocytogenes. All the samples screened were not positive either for Campylobacter jejuni and Listeria monocytogenes. The negative samples were further checked by culture methods and good correlation between these two methods was observed. Hence, the m-PCR technique developed in this study can be used as a rapid screening test for detection of Campylobacter jejuni and Listeria monocytogenes from chicken meat within 24 hours.
\end{abstract}

Keywords: chicken meat, Campylobacter jejuni, Listeria monocytogenes, multiplex polymerase chain reaction

\section{Introduction}

Recently many pathogens such as Listeria monocytogenes, Campylobacter spp., Vibrio spp., etc. have been identified as emerging meat borne diseases. Campylobacter jejuni is present in the gastro intestinal tract of all animals. Due to improper slaughtering method, the carcass may get contaminated with intestinal contents. Contaminated raw or undercooked poultry meats and/or by-products are particularly important to cause food-borne Campylobacteriosis in humans (CDC, 2005). The prevalence of contamination with Campylobacter species were approximately $60 \%$ in any portions of raw poultry meats and by-products except for fillets and hearts (Suzuki \& Shigeki, 2008). Listeria monocytogenes is widely distributed and found in many food commodities. It is very persistent microorganism that survives on surfaces and equipment of food processing units in conditions of insufficient cleaning. Post processing contamination is the major source and cross contamination may also occur at the retail shop and also in products due to improper hygienic practices. Ingestion of uncooked meat contaminated during processing can produce infection. Contaminated raw meat was also a potential source for cross contamination to heat-treated or ready-to-eat products during processing or in the kitchen (Meyer, 2011). L. monocytogenes was found prevalently high in poultry $(24.5 \%)$, intermediate in beef (24.4\%) and less prevalent in pork (21.4\%). Prevalence of L. monocytogenes in the eight isolated strains from ham and sandwiches was $37.5 \%$ and $25.0 \%$ respectively in Italy (Pesavento et al., 2010).

In earlier days, it was customary to sell the freshly slaughtered and dressed hot chicken meat with neither refrigeration nor storage facilities. Currently, increase in population (number of working women), changing life 
style and food habits have propelled consumers to choose hygienic, packed, ready-to-cook meat and meat products. Hence, centralized meat processing units have been established to cater to this demand where there is possible risk of contamination of meat by many microorganisms. Therefore it is necessary to process and handle meat hygienically. Any discrepancy in maintaining the hygienic activities leads to increase in the microbial load in final product. Therefore all processors are opting for the implementation of HACCP in their plants to ensure food safety. It helps in identifying all biological hazards in various processing areas and monitors the critical points for which methods for rapid detection of pathogenic organism are required.

Therefore, there is a thrusting need to develop rapid and reliable method to detect the emerging food pathogens in meat while processing to deliver safe and quality meat and meat products to the consumers. Multiplex PCR is a type of PCR which enables simultaneous amplification of many target sites (template DNA) in one reaction by using more than one pair of primers for different organisms. It helps in minimizing the use of chemicals and also time needed for detecting single organism by normal PCR. Hence, the present study is undertaken for simultaneous detection of Campylobacter jejuni and Listeria monocytogenes from chicken meat by using multiplex polymerase chain reaction.

\section{Materials and Methods}

\subsection{DNA Extraction}

The reference strain of Campylobacter jejuni and Listeria monocytogenes (MTCC 657) was obtained from Department of Veterinary Public Health, Madras Veterinary College, Chennai and Institute of Microbial Technology (IMTECH), Chandigarh. The DNA was extracted by three methods -Bacterial DNA extraction kit method (Qiagen), Phenol-Chloroform-Isoamyl alcohol (25:24:1) extraction method and Boiling method. The genus specific primer was designed targeting Hyp gene: C-Forward: 5'-GGCGTTCATTTGGCGAATTTGAA-3', C-Reverse: 5'-CCGCTGTATTGCTCATAGGGA-3' and prfA gene: L-Forward: 5'-GAGCTATGTGCGATGCCA CTT-3'and L-Reverse: 5'-ATTAGCGAGCAGGCTACCGCAT-3', respectively.

\subsection{Multiplex PCR (m-PCR)}

A $25 \mu \mathrm{l}$ of reaction mixture was set up in $0.2 \mathrm{ml}$ PCR tube with following components such as master mix - 12.5 $\mu 1$, forward primer (Listeria) - $1 \mu \mathrm{l}$, reverse primer(Listeria) - $1 \mu \mathrm{l}$, forward primer (Campylobacter) - $1 \mu 1$, reverse primer(Campylobacter) - $1 \mu 1$, template DNA - $2 \mu 1$ and nuclease free water - $6.5 \mu 1$. The PCR amplification was carried out in Master Cycler Gradient Thermo cycler (M/s. Eppendorf, Germany) with the following cycling of initial denaturation at $94{ }^{\circ} \mathrm{C}$ for 5 minutes, followed by 30 cycles of denaturation $\left(94{ }^{\circ} \mathrm{C}\right.$ for 30 seconds), annealing $\left(52{ }^{\circ} \mathrm{C}\right.$ for 30 seconds) and extension $\left(72{ }^{\circ} \mathrm{C}\right.$ for 30 seconds) and subsequently a final extension at $72{ }^{\circ} \mathrm{C}$ for 7 minutes. The PCR product was subjected to electrophoresis in $2 \%$ agarose gel with ethidium bromide added at a concentration of $1 \mu \mathrm{g} / \mathrm{ml}$ of agarose. Electrophoresis was carried out in $1 \mathrm{X} \mathrm{TAE}$ buffer at 100 volts for 30 minutes. The gel was viewed under UV transiluminator and photographed in gel documentation system.

\subsection{Minimum Detection Limit or Sensitivity of Multiplex PCR}

DNA from reference strain was extracted and quantified using Biophotometer plus (M/s Eppendorf, Germany). The quantified DNA was serially 10 fold diluted in sterile nuclease free water and for each dilution PCR amplification was carried out. Sensitivity of m-PCR in terms of DNA concentration was determined. The highest dilution of the DNA showing a visible band in gel was taken as the detection limit for Campylobacter jejuni and Listeria monocytogenes.

\subsection{Artificial Inoculation of Campylobacter jejuni and Listeria monocytogenes in Chicken Meat}

Pellets obtained from overnight incubated Bolton broth and Brain Heart Infusion broth containing pure cultures of Campylobacter jejuni and Listeria monocytogenes (MTTC 657) respectively were separately suspended in sterile saline solution. The cell numbers were adjusted from $3 \times 10^{8} \mathrm{CFU} / \mathrm{ml}$ to $3 \times 10^{2} \mathrm{CFU} / \mathrm{ml}$ by doing serial 10 fold dilutions. The cell numbers in each dilution were confirmed by plate count method using Blood free Campylobacter Selective agar and Listeria Identification agar (PALCAM).

The chicken meat samples which were negative for Campylobacter jejuni and Listeria monocytogenes were confirmed by culture methods was used for artificial inoculation study. Both of these bacteria in respective tenfold dilutions from $3 \times 10^{8} \mathrm{CFU} / \mathrm{ml}$ to $3 \times 10^{2} \mathrm{CFU} / \mathrm{ml}(0.2 \mathrm{ml}$ of each dilution) were inoculated together in $1.8 \mathrm{ml}$ of meat homogenate obtained by homogenizing 25 gram of chicken meat in $225 \mathrm{ml}$ of BPW. DNA was extracted before pre-enrichment of meat homogenate, by using Bacterial DNA Extraction Kit. The minimum detection level (sensitivity) for m-PCR in terms of number of organisms was determined. The highest dilutions 
of the cultures showing visible bands in gel were taken as the detection limit for Campylobacter jejuni and Listeria monocytogenes.

\subsection{Screening of Chicken Meat Samples}

Around 60 chicken meat samples were collected from different regions of chennai. These samples were screened for the presence of $C$. jejuni and L. monocytogenes by the m-PCR technique developed in this study. The meat homogenate obtained was then subjected to DNA extraction using Phenol-Chloroform-Isoamylalcohol mixture (25:24:1) and m-PCR analysis for the presence of $C$. jejuni and L. monocytogenes. The chicken meat samples, in which either Campylobacter jejuni and Listeria monocytogenes or both were detected by m-PCR, were further confirmed by culture methods.

\section{Results and Discussion}

\subsection{DNA Extraction}

Three methods of DNA extraction were tried, out of which the Phenol Chloroform Isoamyl alcohol (25:24:1) extraction method was found to be cost effective and the purity and concentration of DNA (Table 1) obtained by this method was almost equal to that of Real Genomics DNA extraction kit method. The purity of DNA (OD ratio, $260 \mathrm{~nm}: 280 \mathrm{~nm}$ ) was considered good when the values of OD ratio were between 1.7 and 1.9 (Stephenson, 2010). For boiling method, the purity of DNA was not considered good, the reason for not getting good purity may be due to presence of other compounds than DNA and the other materials are not properly separated or removed during extraction procedure.

Table 1. Mean \pm SE values of purity of DNA and concentration of DNA

\begin{tabular}{lllllll}
\hline \multirow{2}{*}{ DNA Extraction method } & \multicolumn{2}{c}{ Purity (OD ratio) } & & \multicolumn{2}{c}{ Concentration $(\mu \mathrm{g} / \mathrm{ml})$} \\
\cline { 2 - 3 } \cline { 5 - 6 } & C. jejuni & L. monocytogenes & & C. jejuni & L. monocytogenes \\
\hline Qiagen Bacterial DNA extraction kit & $1.85 \pm 0.01$ & $1.86 \pm 0.02$ & & $876.67 \pm 0.92$ & $653.83 \pm 0.87$ \\
Phenol Chloroform Isoamyl alcohol & $1.78 \pm 0.02$ & $1.85 \pm 0.02$ & & $602.50 \pm 0.99$ & $501.83 \pm 0.79$ \\
Boiling method & $1.09 \pm 0.01$ & $1.06 \pm 0.01$ & & $950.17 \pm 0.48$ & $800.83 \pm 0.60$ \\
\hline
\end{tabular}

Among the two extraction methods, Qiagen kit method was best because of higher concentration and purity of DNA which may be due to the presence of spin column which can easily remove or filter the other impurities leaving the DNA. Even though the kit method was considered as best, Phenol-Chloroform-Isoamyl alcohol (25:24:1) extraction method was cost effective. Hence Phenol-Chloroform-Isoamyl alcohol method was standardized and used for further screening of retail chicken meat.

\subsection{Multiplex PCR (m-PCR) Standardization}

Using the genus specific primers newly designed for Campylobacter jejuni and Listeria monocytogenes by targeting the Hyp gene and prfA gene, DNA were amplified which gave the product size of $500 \mathrm{bp}$ and $290 \mathrm{bp}$ respectively by PCR (Figure 1). The multiplex PCR technique was standardized to detect both Campylobacter jejuni and Listeria monocytogenes simultaneously in the same reaction tube (Figure 2). Electrophoresis performed in 2\% agarose, consistently gave good results with $500 \mathrm{bp}$ of Campylobacter jejuni and $290 \mathrm{bp}$ of Listeria monocytogenes. The results of this study were congruent with that of Wang and Slavik (2005) who developed a multiplex PCR assay to detect C. jejuni, E. coli O157:H7, S. typhimurium and L. monocytogenes with amplified PCR products of sizes $159 \mathrm{bp}, 252 \mathrm{bp}, 360 \mathrm{bp}$ and $450 \mathrm{bp}$ respectively. Similar findings were also reported by Yamazaki-Matsune et al. (2007) who developed a multiplex PCR for different species of Campylobacter. 


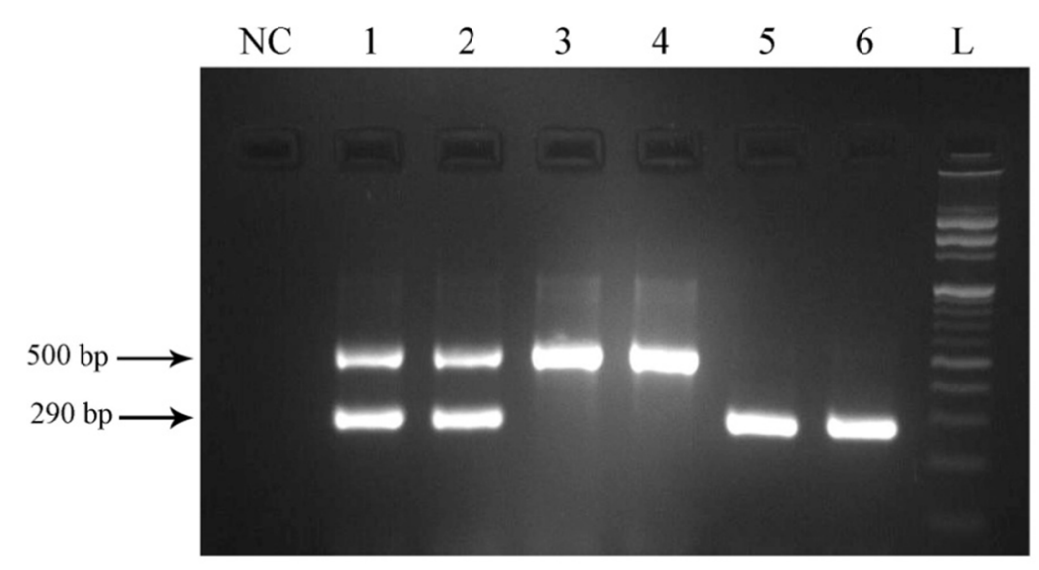

Figure 1. Standardization of PCR and multiplex PCR-Agarose gel electrophoresis of PCR products

Note. L: 100 bp DNA Ladder, 1-2: Campylobacter jejuni and Listeria monocytogenes revealing 500 bp and 290 bp $m$ PCR product of Hyp and prfA gene, 3-4: Campylobacter jejuni revealing 500 bp PCR product of Hyp gene, 5-6: Listeria monocytogenes revealing $290 \mathrm{bp} \mathrm{PCR} \mathrm{product} \mathrm{of} \mathrm{prfA} \mathrm{gene} \mathrm{NC:} \mathrm{Negative} \mathrm{control.}$

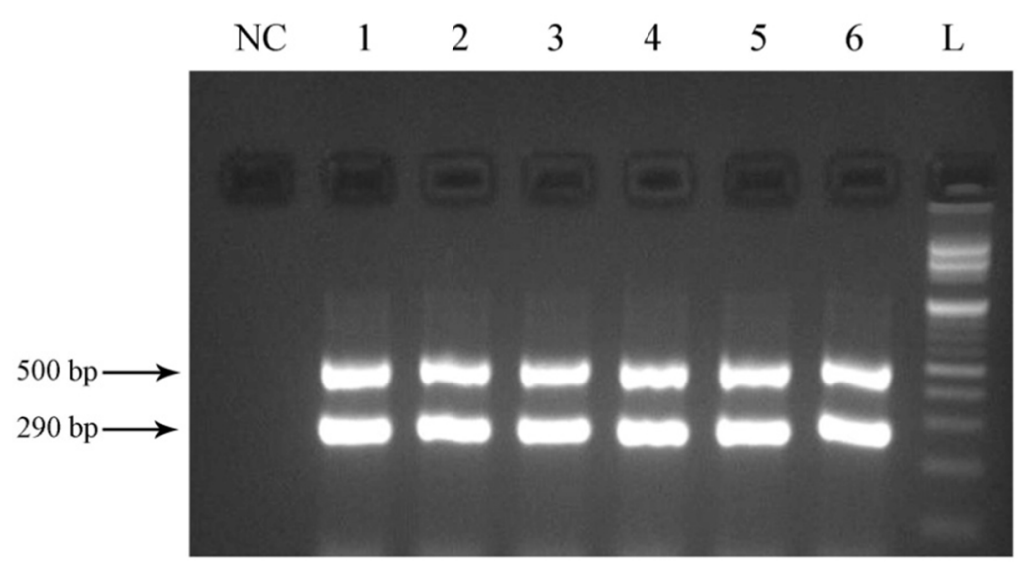

Figure 2. Standardization of m-PCR- Agarose gel electrophoresis of mPCR products

Note. L: 100 bp DNA Ladder, 1-6: Campylobacter jejuni and Listeria monocytogenes revealing 500 bp and 290 bp PCR product of Hyp and prfA gene, NC: Negative control.

\subsection{Sensitivity of Multiplex PCR (m-PCR) for Campylobacter jejuni and Listeria monocytogenes}

Diluted DNA of Campylobacter jejuni and Listeria monocytogenes were used to amplify in the same reaction tube and the sensitivity (minimum detection limit) of Multiplex PCR (m-PCR) for Campylobacter jejuni and Listeria monocytogenes was found to be $0.2 \mathrm{ng} / \mu \mathrm{l}$ and $1.0 \mathrm{ng} / \mu \mathrm{l}$ of DNA in a reaction mixture $(25 \mu \mathrm{l})$ respectively (Figure 3). Related results were obtained by Keramas et al. (2003) who developed a multiplex PCR and detected DNA from $C$. jejuni and $C$. coli to a minimum level of $15-150 \mathrm{fg} / \mu \mathrm{l}$. He also concluded that less sensitivity of bacterial detection was noticed in m-PCR when compared with PCR. The sensitivity in the study was lower when compared to that of Keramas et al. (2003). 


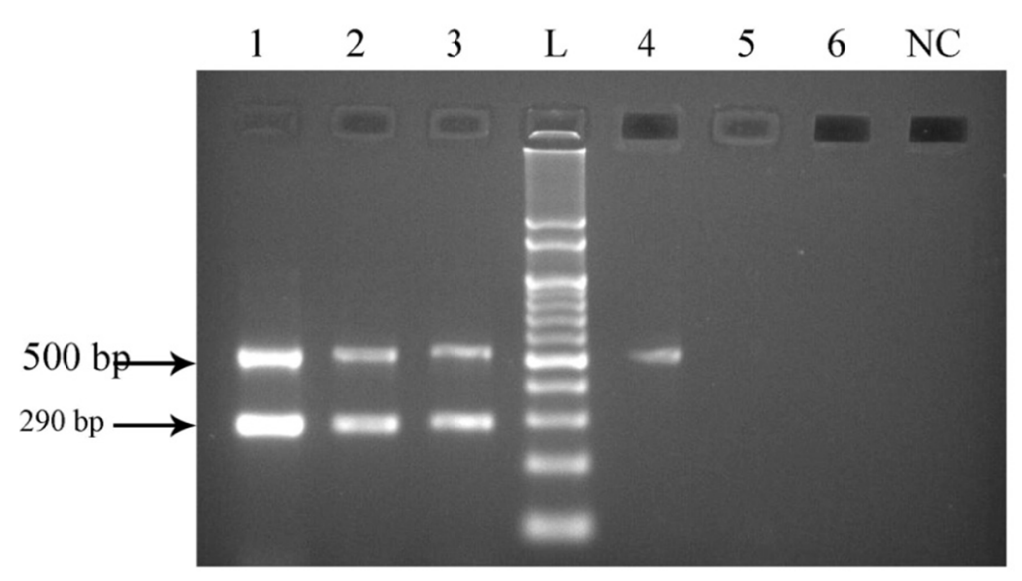

Figure 3. Agarose gel electrophoresis of m-PCR products for Minimum detection level of Campylobacter jejuni and Listeria monocytogenes

Note. L: 100 bp DNA Ladder, 1-6: PCR amplification performed with $200 \mathrm{ng} / \mu \mathrm{l}, 20 \mathrm{ng} / \mu \mathrm{l}, 2 \mathrm{ng} / \mu \mathrm{l}, 0.2 \mathrm{ng} / \mu \mathrm{l}$, $0.02 \mathrm{ng} / \mu \mathrm{l}, 2 \mathrm{pg} / \mu \mathrm{l}$ of Campylobacter jejuni DNA and $100 \mathrm{ng} / \mu \mathrm{l}, 10 \mathrm{ng} / \mu \mathrm{l}, 1 \mathrm{ng} / \mu \mathrm{l}, 0.1 \mathrm{ng} / \mu \mathrm{l}, 0.01 \mathrm{ng} / \mu \mathrm{l}, 1 \mathrm{pg} / \mu \mathrm{l}$ of Listeria monocytogenes DNA respectively. Note no amplification with $0.02 \mathrm{ng} / \mu \mathrm{l}, 2 \mathrm{pg} / \mu \mathrm{l}$ of Campylobacter jejuni DNA and $0.1 \mathrm{ng} / \mu \mathrm{l}, 0.01 \mathrm{ng} / \mu \mathrm{l}, 1 \mathrm{pg} / \mu \mathrm{l}$ of Listeria monocytogenes DNA respectively. NC: Negative control.

\subsection{Artificial Inoculation of Campylobacter jejuni and Listeria monocytogenes in Chicken Meat}

Artificially inoculated reference strains of Campylobacter jejuni and Listeria monocytogenes (MTCC 657) from $3 \times 10^{8} \mathrm{CFU} / \mathrm{ml}$ to $3 \times 10^{3} \mathrm{CFU} / \mathrm{ml}$, DNA was extracted from the meat homogenate and the developed $\mathrm{m}$-PCR technique was used for detection purpose (Figure 4). The sensitivity of Campylobacter jejuni and Listeria monocytogenes were found to be $3 \times 10^{5}$ and $3 \times 10^{4} \mathrm{CFU} / \mathrm{ml}$ of meat homogenate respectively by the developed m-PCR technique. Gilbert et al. (2003) detected bacterial concentrations greater than or equal to $10^{4}$ CFU/reaction for C. jejuni, E. coli, Salmonella and L. monocytogenes. Zhang et al. (2009) developed a m-PCR system for simultaneous detection of Listeria monocytogenes, Staphylococcus aureus, Salmonella enterica and E. coli $\mathrm{O} 157: \mathrm{H} 7$ with a sensitivity as low as $1 \mathrm{CFU} / \mathrm{ml}$ per $25 \mathrm{~g}$ food. Similarly Germani et al. (2009) reported that Listeria alone can be detected at $10^{1}$ cells/ml in PCR, whereas with multiple pathogens in m-PCR they noticed a reduction in detection level of $10^{6} \mathrm{cells} / \mathrm{ml}$. 


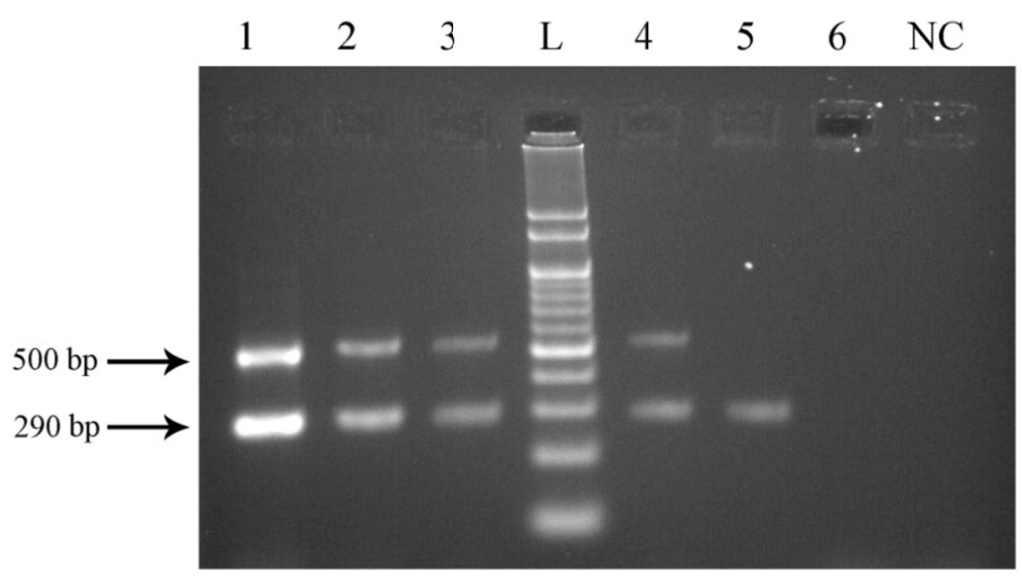

Figure 4. m-PCR amplification for chicken meat sample spiked with Campylobacter jejuni and Listeria monocytogenes

Note. L: 100 bp DNA Ladder; 1-6: PCR amplification performed with $3 \times 10^{8} \mathrm{CFU} / \mathrm{ml}, 3 \times 10^{7} \mathrm{CFU} / \mathrm{ml}, 3 \times 10^{6}$ $\mathrm{CFU} / \mathrm{ml}, 3 \times 10^{5} \mathrm{CFU} / \mathrm{ml}, 3 \times 10^{4} \mathrm{CFU} / \mathrm{ml}, 3 \times 10^{3} \mathrm{CFU} / \mathrm{ml}$ of Campylobacter jejuni and Listeria monocytogenes respectively. Note no amplification with $3 \times 10^{4} \mathrm{CFU} / \mathrm{ml}, 3 \times 10^{3} \mathrm{CFU} / \mathrm{ml}$ of Campylobacter jejuni and $3 \times 10^{3} \mathrm{CFU} / \mathrm{ml}$ of Listeria monocytogenes: NC: Negative control.

\subsection{Sequencing}

PCR products were confirmed by sequencing the samples from Ocimumbio Solutions (P) Ltd, Hyderabad. Then the data were analysed by using Chromas Pro sequencing analysis software and the chromatograph for separate organism with forward and reverse primer (Figures 5, 6, 7 and 8).

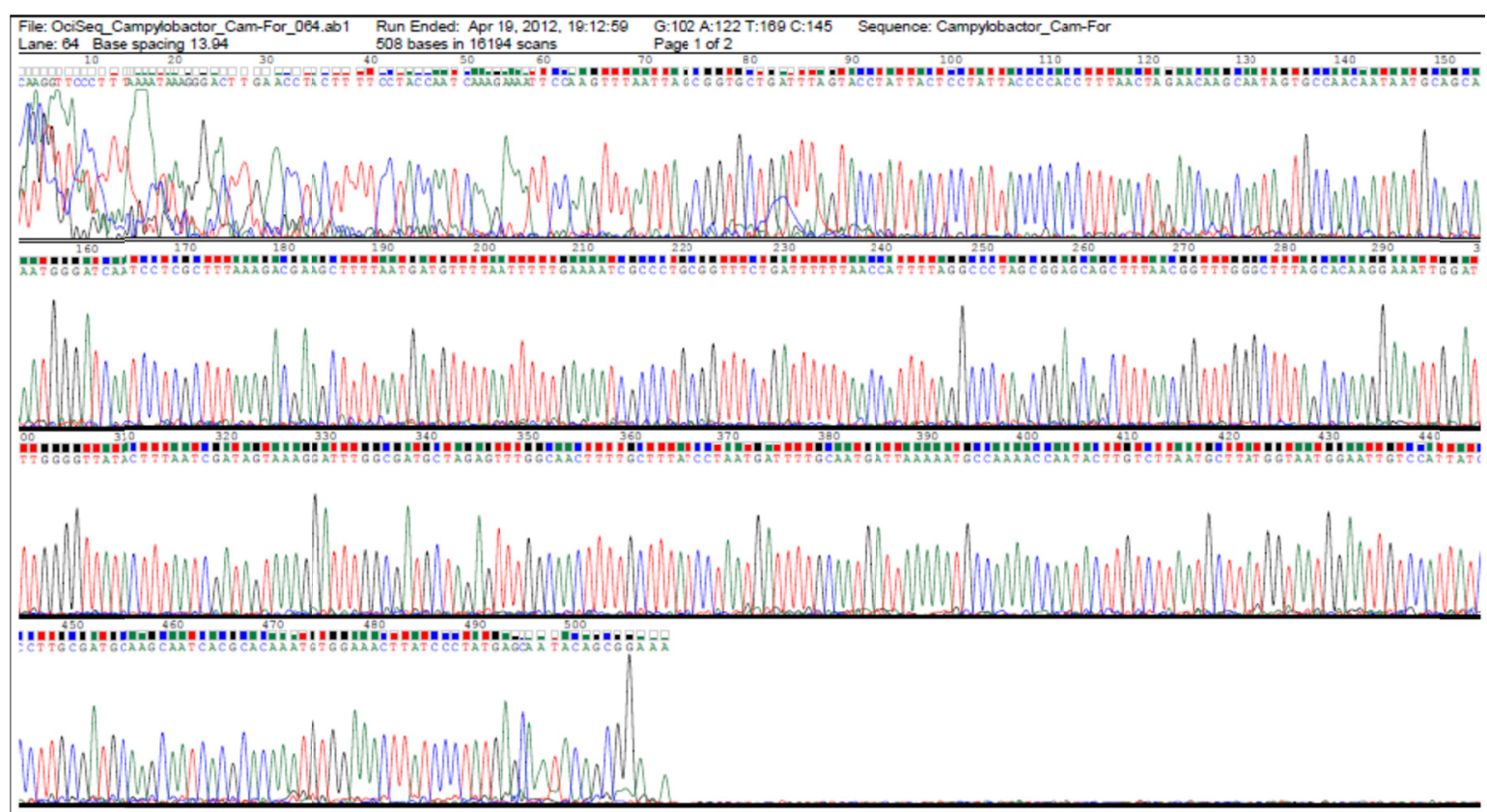

Figure 5. Electropherogram showing amplified DNA sequence data of Hyp gene of Campylobacter jejuni (Forward primer) 
\begin{tabular}{lll}
$\begin{array}{l}\text { File: OciSeq_Campylobactor_Cam-Rev_062.ab1 } \\
\text { Lane: } 62 \text { Base spacing 13.86 }\end{array}$ & $\begin{array}{l}\text { Run Ended: Apr 19. 2012. 19:12:59 } \\
\text { 504 bases in 16241 scans }\end{array}$ & $\begin{array}{l}\text { G:121 A:182 T:218 C:212 } \\
\text { Page } 1 \text { of } 2\end{array}$ \\
\hline
\end{tabular}

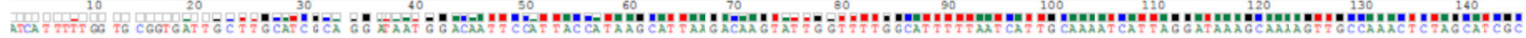

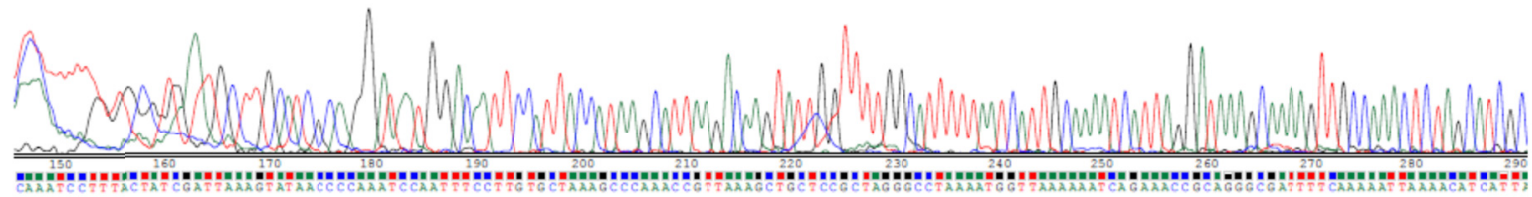

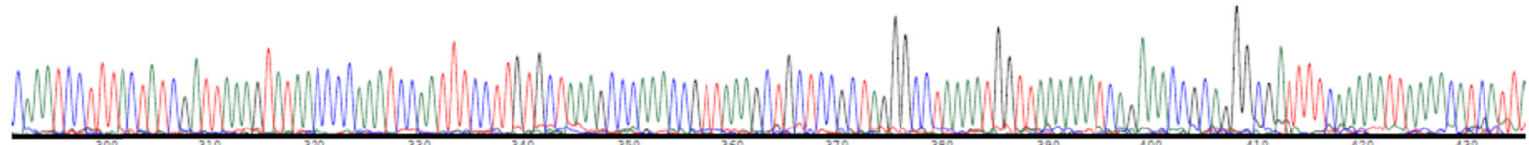

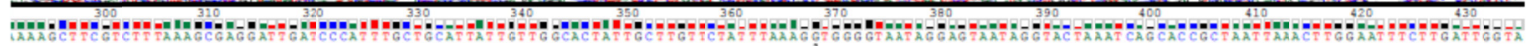

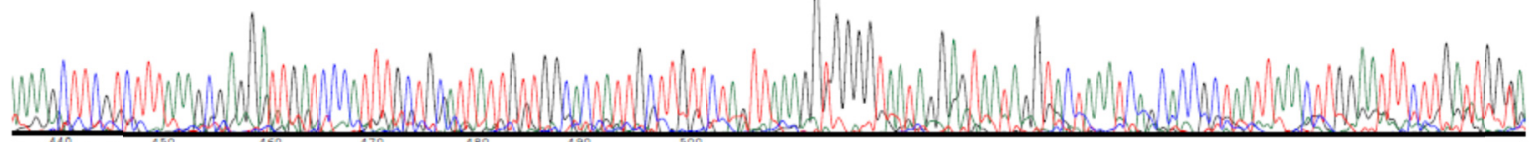

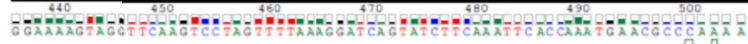

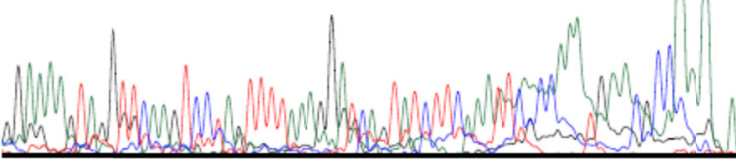

Figure 6. Electropherogram showing amplified DNA sequence data of Hyp gene of Campylobacter jejuni (Reverse primer)

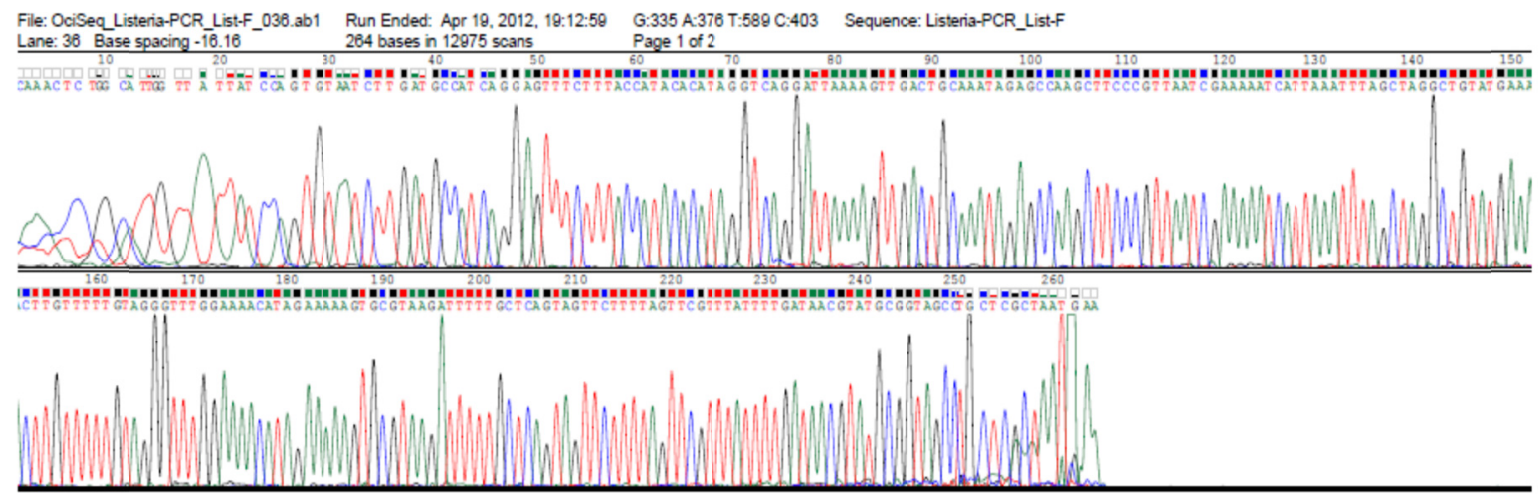

Figure 7. Electropherogram showing amplified DNA sequence data of prfA gene of Listeria monocytogenes (Forward primer)

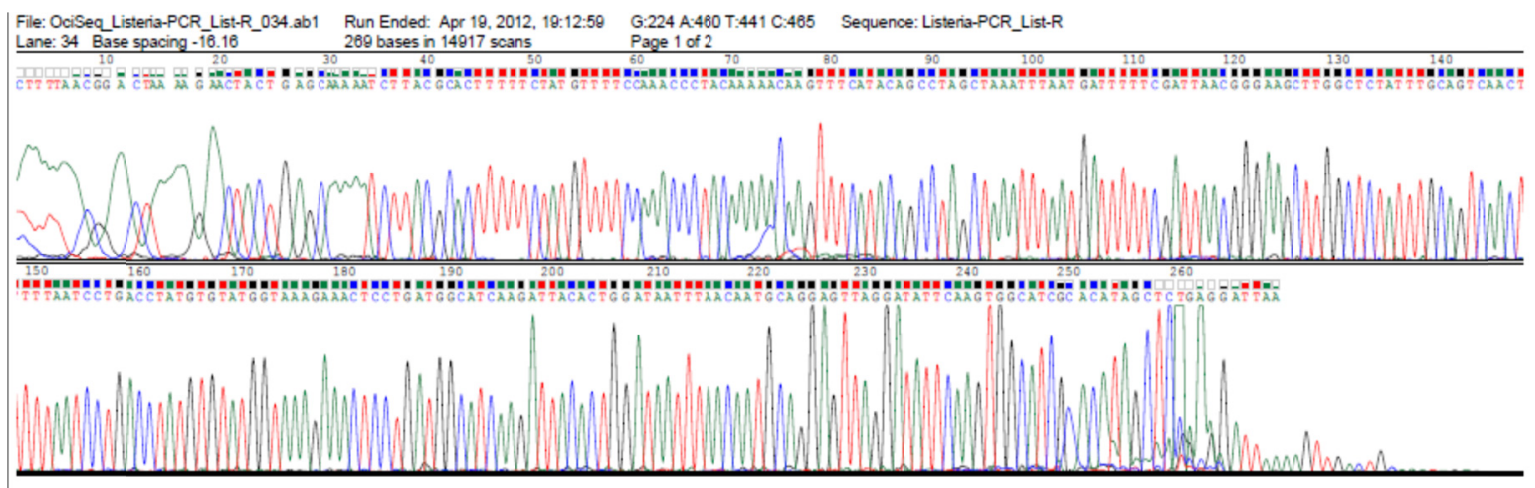

Figure 8. Electropherogram showing amplified DNA sequence data of prfA gene of Listeria monocytogenes (Reverse primer) 


\subsection{Screening of Chicken Meat Samples by Multiplex PCR (m-PCR)}

In this study, screening of chicken meat samples from retail outlets were carried out to assess the usefulness of the developed m-PCR technique. All the samples screened were not positive either for Campylobacter jejuni and Listeria monocytogenes. The negative samples were further checked by culture methods and good correlation between these two methods was observed. Rahimi et al. (2010) found higher prevalence of Campylobacter $(61.7 \%)$ in chicken meat from retail markets of Iran. Similarly Kozacinski et al. (2006) conducted a study to assess the microbial quality of chicken meat in Croatian market and reported L.monocytogenes in chicken breast and skin $(4.76 \%)$ but Campylobacter jejuni were absent in analysed samples. Similar findings reported by Ahmed and Nashwa (2010) who detected L. monocytogenes in chicken meat (16\%). Hence, the m-PCR technique developed in this study can be used as a rapid screening test for detection of Campylobacter jejuni and Listeria monocytogenes from chicken meat within 24 hours.

\section{Conclusion}

DNA extraction by Phenol Chloroform method was good in purity as well as concentration and cost effective. The developed m-PCR technique could able to detect Campylobacter jejuni and Listeria monocytogenes from chicken meat within 24 hours even with minimum concentration level of $0.2 \mathrm{ng} / \mu \mathrm{l}$ and $1.0 \mathrm{ng} / \mu \mathrm{l}$ of DNA in a reaction mixture $(25 \mu \mathrm{l})$. Hence it can be used as rapid screening test.

\section{References}

Ahmed, M. A., \& Abd El-Atti, N. M. (2010). Existence of Listeria species in broiler carcasses with an attempt to control Listeria monocytogenes using trisodium phosphate. African Journal of Food Science, 4, 46-51.

Germini, A., Masola, A., Carnevali, P., \& Marchelli, R. (2009). Simultaneous detection of Escherichia coli O175:H7, Salmonella spp., and Listeria monocytogenes by multiplex PCR. Food Control, 20, 733-738. http://dx.doi.org/10.1016/j.foodcont.2008.09.010

Gilbert, C., O'leary, A., Winters, D., \& Slavik, M. (2003). Development of a multiplex PCR assay for the specific detection of Salmonella, Campylobacter jejuni, Escherichia coli O157:H7, and Listeria monocytogenes. Journal of Rapid Methods and Automation in Microbiology, 11, 61-74. http://dx.doi.org/ 10.1111/j.1745-4581.2003.tb00409.x

Keramas, G., Bang, D. D., Lund, M., Madsen, M., Rasmussen, S. E., Bunkenborg, H., ... Christensen, C. B. V. (2003). Development of a sensitive DNA microarray suitable for rapid detection of Campylobacter spp. Molecular and Cellular Probes, 17, 187 196. http://dx.doi.org/10.1016/S0890-8508(03)00052-5

Kozacinski, L., Hadziosmanovic, M., \& Zdolec, N. (2006). Microbiological quality of poultry meat on the Croatian market. Veterinarski Arhiv, 76, 305-313.

Meyer, C., Fredriksson-Ahomaa, M., Sperner, B., \& Märtlbauer, E. (2011). Detection of Listeria monocytogenes in pork and beef using the VIDAS ${ }^{\circledR}$ LMO2 automated enzyme linked immunoassay method. Meat Science, 88, 594-596. http://dx.doi.org/10.1016/j.meatsci.2011.01.035

Pesavento, G., Ducci, B., Nieri, D., Comodo, N., \& Lo Nostro, A. (2010). Prevalence and antibiotic susceptibility of Listeria spp. isolated from raw meat and retail foods. Food Control, 21, 708-713. http://dx.doi.org/10.1016/j.foodcont.2009.10.012

Rahimi, E., Kazemeini, R, H., Safaei, S., Allahbakhshi, K., Momeni, M., \& Riahi, M. (2010). Detection and identification of Campylobacter spp. from retail raw chicken, turkey, sheep and goat meat in Ahvaz, Iran. African Journal of Microbiology Research, 4, 1620-1623.

Stephenson, F. H. (2010). Calculation in molecular biology and biotechnology. Academic Press.

Suzuki, H., \& Yamamoto, S. (2008). Campylobacter contamination in retail poultry meats and by-products in the world: A literature survey. Public Health.

Wang, H., \& Slavik, M. F. (2005). A multiplex polymerase chain reaction assay for rapid detection of Escherichia coli O157:H7, Listeria monocytogenes, Salmonella typhimurium and Campylobacter jejuni in artificially contaminated food samples. Journal of Rapid Methods and Automation in Microbiology, 13, 213-223. http://dx.doi.org/10.1111/j.1745-4581.2005.00015.x

Yamazaki, M. W., Taguchi, M., Seto, K., Kawahara, R., Kawatsu, K., Kumeda, Y., ... Tsukamoto, T. (2007). Development of a multiplex PCR assay for identification of Campylobacter coli, Campylobacter fetus, Campylobacter hyointestinalis subsp. hyointestinalis, Campylobacter jejuni, Campylobacter lari and 
Campylobacter upsaliensis. Journal of Medical Microbiology, 56, 1467-1473. http://dx.doi.org/10.1099/ jmm.0.47363-0

Zhang, D., Zhang, H., Yang L., Guo, J., \& Feng, X. L. Y. (2009). Simultaneous detection of Listeria monocytogenes, Staphylococcus aureus, Salmonella enterica and Escherichia coli O157:H7 in food samples using multiplex PCR method. Journal of Food Safety, 29, 348-363. http://dx.doi.org/10.1111/ j.1745-4565.2009.00161.x

\section{Copyrights}

Copyright for this article is retained by the author(s), with first publication rights granted to the journal.

This is an open-access article distributed under the terms and conditions of the Creative Commons Attribution license (http://creativecommons.org/licenses/by/4.0/). 